\title{
Tozlu Ortamlarda Çalışanların Sağlığı Üzerine Tozun Etkileri*
}

\author{
Effects of Dust on the Health of Workers in Dusty Environments
}

\author{
Temuçin ÖZKAN (D) , Zehra YILDIZ
}

\begin{abstract}
ÖZET
İş yeri ortamında solunan hava içeriğindeki toz, birçok sanayi kolunda çalışanların sağlığına zarar vermektedir. Endüstriyel işletme faaliyetleri sonucunda işyerinde oluşan tozların uygun toz azaltma veya engelleme yöntemleri uygulanarak tozlu ortamlarda iş sağlığı ve güvenliği sağlanmalıdır. Çalışma ortamındaki toz maruziyeti, pnömokonyoz, asbestoz ve siderozis silikoz gibi birçok meslek hastalığına sebep olmaktadır. Bu çalışmada tozlu ortamda çalışanların maruz kaldığı toz türleri, toz sınır düzeyleri, maruz kalınan tozun çalışan sağlığı üzerindeki etkileri, toz maruziyeti ile ilgili mevzuatlar, tozun sebep olduğu meslek hastalıkları ve korunma yöntemleri değerlendirilmiștir.
\end{abstract}

Anahtar Kelimeler: Toz maruziyeti, Mesleki solunum yolu hastalıkları, Mesleki akciğer hastalıkları

\begin{abstract}
Dust in the air content inhaled in the workplace environment harms the health of employees in many industries. Diseases caused by inhalation of dust into the lungs are generally in the form of tissue reaction caused by the accumulation of inorganic dusts in the lungs. It is known that there are dozens of diseases such as coal worker pneumoconiosis, asbestosis, siderosis silicosis caused by dust exposure. Although various reduction techniques are used for dusting as a result of business activities, it is still a known fact that respirable dusts pose a risk to the health of employees. In this study, the dust levels that the workers are exposed to in the dusty environment, the effects of the dust exposed on the worker health and the relevant legislation were evaluated. Keywords: Dust exposure, Occupational respiratory diseases, Occupational lung diseases
\end{abstract}

Temuçin ÖZKAN I temucinozkan@gmail.com

Tarsus Üniversitesi, Lisansüstü Eğitim Enstitüsü, Mersin, Türkiye

Tarsus University, Gradute School of Education, Mersin, Turkey

Zehra YILDIZ | zyildiz@tarsus.edu.tr | Sorumlu Yazar/Corresponding Author Tarsus Üniversitesi, Mühendislik Fakültesi, Mersin, Türkiye

Tarsus University, Faculty of Engineering, Mersin, Turkey

* Bu çalışma Doç. Dr. Zehra YILDIZ danışmanlığında Temuçin ÖZKAN tarafindan Ocak 2021 tarihinde tamamlanan "Çimento Üretim Sektöründe Toz Seviyelerinin Belirlenmesi ve Çalışanlar Üzerindeki Etkilerinin İncelenmesi" başlıklı ve 661053 tez no'lu yüksek lisans tezinden türetilmiştir. 


\section{GİRIŞ}

Toz, kııım, parçalama, yıkım, frezeleme, öğütme, taşıma, delme faaliyeti, taraklama, paket yapma, süpürme ile küreme gibi mekanik işlemler sonucu oluşan çökebilen ya da havada asılı kalan katı taneciklerdir. İş sağlığı açısından işyerinin ortam havasına yayılmış olan boyutları 0.5-100 $\mu \mathrm{m}$ parçacıklar solunabilir olduğundan çalışanların sağlığını tehlikeye sokmaktadır. Toz boyutu $100 \mu \mathrm{m}$ den fazla olan tanecikler yerçekimi etkisinden dolayı çöktüğünden nefes yoluna giremeyip sağlık riski oluşturmazlar [1,2].

İş yeri ortamında solunan hava içeriğindeki toz, başta madencilik ve çimento sektörü gibi tozlu ortamlarda çalışılan birçok sanayi kolunda çalışanın sağlığı için tehdit oluşturmaktadır. Toz maruziyeti en fazla tünel, yol ve baraj yapımı gibi işler, çırçır prese işleri, maden ocakları, döküm ve kumlama-raspa faaliyetleri, tahıl depolanan siloları, sigara ve un fabrikaları, ağaç işleme tesisleri, yüzey işleme tesisleri ile kiremit, tuğla, çimento, porselen, mermer, demirçelik ve metal sanayiinde meydana gelmektedir [3].

Dünyada en fazla teşhis konulan meslek hastalıkları, tozlu ortamlarda çalışanlarda daha sık rastlanan mesleki solunum yolları hastalıklarıdır. Akciğer ve solunum sistemi meslek hastalıklarına berilyum, kadmiyum, krom, nikel, arsenik, asbest ve silikan gibi maddeler sebep olmaktadır. Mesleki solunum yolları hastalıklarından mesleki akciğer hastalıkları, dünya genelinde işçi sağlığı tehdit eden çok önemli bir sorundur. Mesleki akciğer hastalıklarında karşılaşılan en büyük zorluk, üretim koşullarının, iş hayatındaki düzenleme farklılı̆ııın meslek hastalıkları tanı ve bildirim sistemine etkisini belirlemektir. İşyeri kaynaklı akciğer hastalıkları diğer meslek hastalıklarının birçoğunda olduğu gibi yeterince sistemli bir şekilde kayıt alına alınmamaktadır. Mesleki etkilenim sonucu ortaya çıkan asbestozis akciğer hastalıkları nedeniyle yılda 7000, silikozise bağlı olarak
9000, kömür iş̧̧isi pnömokonyozuna bağlı olarak ise 14.000 kişi, yaklaşık 102.000 kişi akciğer ve solunum yolu kanseri sebebiyle yaşamını yitirmektedir [4].

Mesleksel akciğer hastalıkları içerisinde en sık görüleni mesleki astım olup, radyolojik bulgu vermemektedir. Buna karşın, sadece mesleki akciğer hastalıklarında değil, tüm mesleki hastalıklar içerisinde radyolojinin en fazla öne çıtığı mesleki hastalık pnömokonyozlardır. Pnömokonyoz, pek çok çeşitli toz veya kimyasalların uzun süreli solunmasıyla oluşan akciğer hastalıklarının ortak adıdır. En yaygın meslek hastalıklarından biridir ve mineral veya organik tozun solunması ve zayıf kişisel korunma ile ilişkilidir [57].

Dünya Sağlık Örgütü, mesleki etkileşim kaynaklı ölümler arasında ilk sırada 318.000 kişinin ölümüne yol açan kronik obstruktif akciğer hastalıklarıdır (KOAH). Ayrıca KOAH, astım ve akciğer-solunum yolu kanserleri gibi rahatsızlıkların çok etmenli etiyolojiye sahip olması ve uzun sürelerde meydana gelmesi söz konusu rahatsızlıkların mesleki kapsamda kategorize edilmesini zorlaştırmaktadır. KOAH vakalarının \%10-15'inin, akciğerlerde ve solunum yollarında oluşan kanserlerin $\% 25$ 'inin ve yetişkin astım vakalarının \%15-20'sinin mesleksel etkilenimkaynaklı olduğu bilinmektedir $[8,9]$.

Bu çalışmada mesleki solunum yolu hastalıkları, meslek hastalıklarından korunma, toz maruziyeti, tozun sağlığa etkileri ve tozla ilgili mevzuatlar değerlendirilmiştir.

\section{MESLEKI SOLUNUM YOLU HASTALIKLARI}

Meslek hastalıkları, doğrudan yapılan işten kaynaklanan hastalıklar olup, büyük ölçüde "önlenebilir” olan sağlık problemleridir. İşyerlerinde hastalıklara sebep olan bu unsurlar içerisinde; fiziksel, kimyasal ve biyolojik etkenler, tozlar, ergonomik ve psikososyal faktörler yer almaktadır. 
"İş" kaynaklı hastalık yapııı bu etkenler uygun metotlarla kontrol altına alındığında meslek hastalıklarının oluşma riski minimize edilebilir [10].

Meslek hastalığının en önemli unsuru; çalışanın uğradığ 1 bedensel ya da ruhsal engellilik ile çalışıı̆g iş arasında bir neden-sonuç ilişkisinin diğer bir deyişle illiyet bağının bulunmasıdır. Meslek hastalığının, çalışanın yaptığı işe ve bu işin niteliklerine bağlı olarak tekrarlanan bir nedenle veya işin yürütümüyle ilgili koşullardan kaynaklanan bir nedenle zamanla ortaya çıkar [11]. Meslek hastalığı problemleri, çalışana özgü klinik bir vaka ile ortaya çıkabilir, deneysel olarak oluşturulabilir, birçok etkenin birleştiği hastalık bileşeni ile birlikte veya metabolitenin biyolojik ortamlarda bulunuşu ile ortaya çıkartabilir. Meslek hastalıkları belirli mesleklere özgü hastalıklar olarak ele alınır ve çalışılan işle doğrudan neden-sonuç bağlantısı olduğu kabul edilir [12].

Hastalığın yükseliş hızı belirli bir meslekte çalışanlarda yüksek olarak görülmesi de meslek hastalıklarının genel özellikleri arasındadır. İş ile alakalı olarak oluşan hastalıklarsa birbirinden farklı etkenlerle ortaya çıkabilecek çalışma yaşamındaki bileşenler veya şartlar sebebiyle gelişiminin artması ve hızlanmasıyla karakterizedir [13].

Mesleki etkilenim sonucu çalışanda teşhisi konulan geleneksel meslek hastalıkları yanısıra çalışma hayatındaki değişikliklere bağlı olarak yeni meslek hastalığı türleri de ortaya çıkmıştır. Meslek hastalıkları genel olarak A, B, C, $\mathrm{D}$ ve $\mathrm{E}$ grubu olmak üzere beş gurup altında incelenmekte olup, meslek hastalıklarının sınıflandırılması Tablo 1 de verilmiştir [14]. Bu sınıflandırma da tozlara bağlı olan meslek hastalıkları $\mathrm{C}$ grubu içerisinde yer almaktadır. ILO’nun meslek hastalıkları sınıflandırılmasında meslek hastalığına sebep olan etkenler ve etkilenen vücut bölümlerindeki sağlık sorunları ve mesleğe bağlı kanserleri de içerecek şekilde sınıflandırmıştır. Bu sınıflandırmada solunum sisteminin meslek hastalıkları, hedef organlarda görülen meslek hastalıkları arasında yer almaktadır [15].

Tablo 1: Mesleki hastalıklarının sınıflandırılması

\begin{tabular}{|c|c|}
\hline \multicolumn{2}{|c|}{ Meslek Hastalıkları } \\
\hline A Grubu & $\begin{array}{l}\text { Kimyasal maddeye maruz kalınması sonucu oluş- } \\
\text { maktadır (Kimyasal madde/gaz kullanımına bağlı } \\
\text { olarak kuşun, kadmiyum, civa ve karbon monoksit } \\
\text { zehirlenmesi) }\end{array}$ \\
\hline B Grubu & $\begin{array}{l}\text { Mesleki maruziyet sonucu ciltte oluşan hastalıkları } \\
\text { içermektedir (deri kanseri ve alerjik cilt hastalıkları) }\end{array}$ \\
\hline C Grubu & $\begin{array}{l}\text { Tozlara bağlı olan meslek hastalıkları } \\
\text { (pnömokonyozlar: Akciğerde Toz birikmesi- KOAH, } \\
\text { solunum yetersizliği, pnömotoraks) }\end{array}$ \\
\hline D Grubu & $\begin{array}{l}\text { Biyolojik etkenlere maruz kalınması sonucu olu- } \\
\text { şan meslek hastalıklarını içermektedir (sıklıkla } \\
\text { sağlık ve tarım/hayvancılık sektöründe çalışanlarda) }\end{array}$ \\
\hline E Grubu & Fiziksel etkenlere bağlı meslek hastalıkları \\
\hline
\end{tabular}

Amerika'daki İşçi Sağlığı ve Güvenliği Ulusal Enstitüsü’ne göre iş̧̧i sağlığı problemi kapsamında kaygı bozukluğu, hayal kırıklığı ve sinirsel hastalıklar, solunum yolu hastalıkları, işitme ve duyu kayıpları, cilt hastalıkları, kan ile bulaşan hastalıklar, kas ve iskelet sistemi hastalıkları, kurşun toksisitesi ve zehirlenmeler olmak üzere 8 farklı sağlık problem ve hastalık bulunmaktadır [16].

Uluslararası Çalışma Örgütünün hazırladığı rapora göre meslek hastalıkları ve iş kazaları kaynaklı ölüm sayısının 2.3 milyon işçi olduğu belirlenmiştir. Bir günde 6.300 işçinin 5.500 'ü meslek hastalıkları nedeniyle yaşamını yitirdiği ve yılda 160 milyon kişinin ise meslek hastalıklarına yakalandığı tahmin edilmektedir [17].

İngiltere’ye bağlı sağlık ve sosyal sorunlardan sorumlu kuruluş olan HSE (Health Service Executive) kurumunun 2014 yılında İngiltere'de yaptığı bir çalışmada mesleki solunum rahatsızlıkları incelenmiştir. Bir yıl içinde iş hayatındaki 33000 bireyde meslek maruziyeti sonucu solunuma ve akciğere bağlı bir sorun yaşandığı belirtilmiştir. 141000 çalışanda akciğer ve solunum hastalıklarının mesleki maruziyetler sonucu oluştuğu anlaşılmışıı. Çalışanların yaş ortalaması 53 olup, 65 yaş üstünde çalışanların oranı \%25 dir. 
Bu çalışmada, solunumla ve akciğerle ilgili rahatsızlıkların çok büyük bir kısmının çalışma hayatının ilerleyen yaşlarında veya emeklilik dönemlerinde ortaya çıktığı belirlenmiştir. Solunum ve akciğere bağlı sorunları olan çalışanların \%20 si kesim taş, beton kaynaklı toz, tuğla tozu ve çimento bölümlerinde çalışmaktadır [18]. Şekil 1'te görüleceği üzere dünyada yapılan işe bağlı ölümlerin \%8'inin solunum sistemi kaynaklı hastalıklardan kaynaklandığı görülmektedir [19].

Şekil 1: Dünyada işe bağlı yıllık ölüm oranları

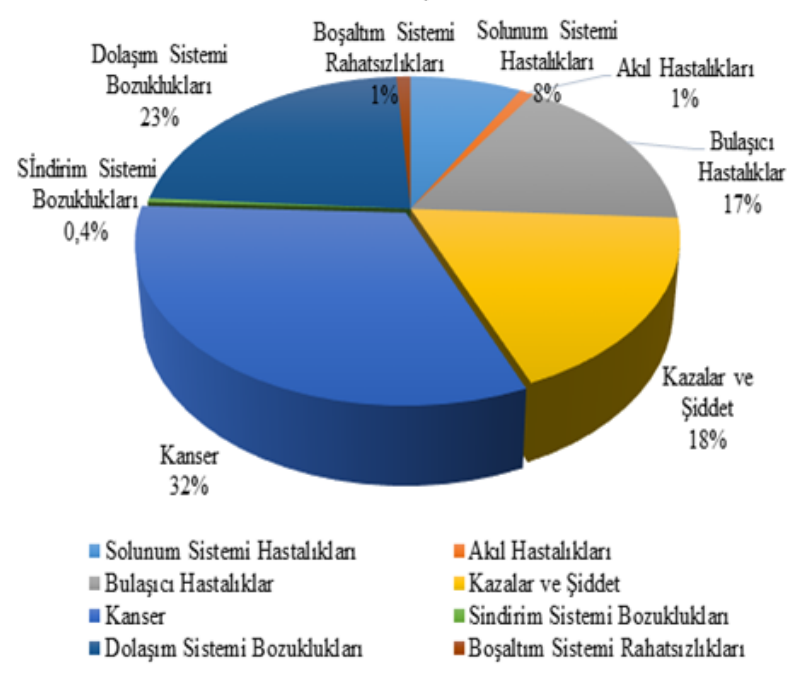

Dünya Sağlık Örgütü, mesleki etkileşim kaynaklı ölümler arasında ilk sırada 318.000 kişinin ölümüne yol açan KOAH bağlı ölümlerin olduğunu belirtmiştir. $\mathrm{KOAH}$, astım ve akciğer - solunum yolu kanserleri vb. rahatsızlıkların çok etmenli etiyolojiye sahip olması ve uzun sürelerde meydana gelmesi (uzun latent periyodları) söz konusu rahatsızlıkların mesleki kapsamda kategorize edilmesini zorlaştırmaktadır. KOAH vakalarının \%1015 'inin, akciğerlerde ve solunum yollarında oluşan kanserlerin \%25'inin ve yetişkin astım vakalarının \%15-20'sinin mesleksel etkilenim kaynaklı olduğu bilinmektedir [8, 9].

2010 yılında Çin Halk Cumhuriyetinde tanısı konulmuş olan 27.240 meslek hastalığı vakasının 23.812'si çalış- ma ortamında oluşan tozdan kaynaklanan mesleki solunum sistemi hastalığı tespit edilmiştir. 2011 tarihinde Japonya'da tanısı konulmuş olan meslek hastalıklarının 3'te 1'i pnömokonyoz olduğu ve İngiltere'de 2011 tarihinde tanısı konulmuş olan her 3 meslek hastalığından 2'si pnömokonyoz ve mezotelyoma olduğu belirlenmiştir [8].

Morbidite ve mortalite verileri, meslek hastalıklarının ve özellikle mesleki akciğer hastalıklarının dünya genelinde halk sağlığı açısından çok önemli bir sorunu olduğunu göstermektedir. Mesleki akciğer hastalıklarında karşılaşılan en büyük zorluk, üretim koşullarının, iş hayatındaki düzenlemelerin farklılıklarının meslek hastalıkları tanı ve bildirim sistemine etkisini belirlemektir.

\section{TOZUN SAĞLIĞA ETKILLERI}

Çalışanlarda toz oluşumuna sebep olan faaliyetler sonucu sağlığı tehdit eden riskler, tozun türüne ve maruziyet durumuna bağlı olarak gelişmektedir. Buradaki maruziyet durumu, havadaki toz zerreciğinin konsantrasyonu, parçacığın aerodinamik çapı ve maruz kalma süresiyle bağıntılıdır. Ayrıca solunum hızı ile soluk alma miktarının seviyesi de maruziyet düzeyini olumlu veya olumsuz etkileyebilen unsurlardır [2].

Solunan tozların vücutta depolanma durumu ilk olarak tanecik çapı ile ilgilidir. $10 \mu \mathrm{m}$ dan büyük aerodinamik çapa sahip bütün toz parçacıkları burnun mukozasında birikmekte olup, 3-10 $\mu \mathrm{m}$ çapı aralığındaki tanecikler ise yutak ile trakeobronşiyal ağaç üzerinde birikmektedirler. 0,1-3 $\mu \mathrm{m}$ aerodinamik çapa sahip toz tanecikleri genellikle alveoller içerisinde birikmektedirler. Çapı $0,1 \mu \mathrm{m}$ un altında olan tanecikler ise hava akımı içerisinde kalmakta olup, soluk alış-veriş aşamasında dışarıya atılırlar [20].

Toz zerreciklerinin sağlığımız üzerindeki etkileri akut olmaktan çok kroniktir. Çok uzun süreli toz imisyon kirli- 
liğine maruz kalındığı durumlarda akciğerde partikül birikmesine bağlı sağlık problemleri oluşmaktadır [21]. Çeşitli mineral tozlarına karşı akciğerlerin reaksiyonları, partiküllerin boyutu, şekli, suda çözülmesi ve reaktivitesine bağl1 olarak değişmektedir. Madenlerde, açık ve kapalı işletmelerde tozlu ortamlarda çalşanların gördüğü zararın boyutu; tozlu ortamlarda çalsşılan süre, tozun karışımı, tozun yoğunluğu, tanecik boyutu ve tozlara karşı çalışanların kişisel hassasiyet durumuna bağlı olarak değişlik göstermektedir [22]. Kömür tozu inert sayılabilir ve buna bağlı akciğer hastalıklarının klinik bulgu verebilmesi için çok miktarda toz birikiminin solunması gerekmektedir. Asbest, silika ve berilyum gibi tozlar ise kömür tozuna göre daha reaktiftir ve daha düşük maruziyet durumlarında akciğerin yapısını bozar ve bağ dokusu artısıına sebep olmaktadır.

Maruziyet durumlarında partiküllerin yarattığı konsantrasyon ve maruz kalma süreleri hastalığın oluşumunun seyrini belirleyen temel etmenlerdendir. Fazla miktardaki partikülmaruziyeti ani gelişen akciğer iltihabına sebep olabilirken, uzun zamanlar içinde biriken küçük miktarlardaki partiküller ilerleyici akciğer küçülmesine sebep olurlar. Sigara kullanımı asbest başta olmak üzere solunan tüm mineral tozlarının akciğerlere olan zararlı etkilerini artırmaktadır [23].

Minerallerin insan sağlığına etkileri ve neden oldukları hastalıklar Tablo 2'de gösterilmiştir [24].

\section{A. Tozla İlgili Yasal Düzenlemeler}

Birçok çalışma alanında toz oluşturan faaliyetlerle karşılaşmak mümkündür. En fazla toz maruziyeti: Kırma, patlatma, öğütme ve delme işleri; Tünel, yol ve baraj yapımı; Maden işletme ocakları; Grafit veya kum gibi her türlü döküm faaliyetleri; Kiremit ve tuğla sanayii; Çimento sanayii; Porselen sanayii; Mermer sanayii; Kaynak faaliyetleri; Pamuklu kumaş, çıçıı prese işleri; Tahıl depolanan silolar,
Tablo 2: Çeşitli mineraller ile neden oldukları hastalıklar

\begin{tabular}{|c|c|}
\hline Mineralin Adı & Neden Olduğu Hastalıklar \\
\hline $\begin{array}{l}\text { Eser Elementler (Demir, Bakır, } \\
\text { Kurşun, Magnezyum, Çinko, } \\
\text { Manganez, Kobalt, Krom, Selen- } \\
\text { yum, Molibden, İyodin Vs.) }\end{array}$ & Metabolizmadaki Bütün Prosesler \\
\hline $\begin{array}{l}\text { Asbest Grubu (Krizotil, Krosido- } \\
\text { lit, Tremolit, Amasit, Antofillit, } \\
\text { Aktinolit) }\end{array}$ & $\begin{array}{l}\text { Akciğer, Plevra, Periton, Ovaryum, } \\
\text { Mide, Pankreas, Böbrek, Üst Sindi- } \\
\text { rim Yolu Ve Solunum Yolu Kanser- } \\
\text { leri, Hyalanize Kalsifiye Plevral } \\
\text { Plaklar, Pulmoner Fibrozis. }\end{array}$ \\
\hline $\begin{array}{l}\text { Kuvars Grubu (Ametist, Tridimit, } \\
\text { Kristobalit, Keatit, Koesit, Stisha- } \\
\text { vit, Kalsedon, Sileks) }\end{array}$ & Pnömokonyoz \\
\hline $\begin{array}{l}\text { Kömür Grubu (Taşkömürü, Tur- } \\
\text { ba, Linyit, Antrasit) }\end{array}$ & Pnömokonyoz \\
\hline $\begin{array}{l}\text { Silikat Grubu (Fenakit, Olivin, } \\
\text { Alümino Silikatlar, Gröna, Epi- } \\
\text { dot) }\end{array}$ & $\begin{array}{l}\text { Pulmonar Fibrozis, Hyalanize Kalsi- } \\
\text { fiye Plevral Plaklar }\end{array}$ \\
\hline $\begin{array}{l}\text { Zeolit Grubu (Analsim, Lösit, } \\
\text { Natrolit, Şabazit, Höylandit, } \\
\text { Stilbit) }\end{array}$ & $\begin{array}{l}\text { Plevra ve Periton Kanserleri, Plevra } \\
\text { Kalınlaşması, Kalsifiye Plevral Plak- } \\
\text { lar }\end{array}$ \\
\hline $\begin{array}{l}\text { Radyoaktif Grubu (Uraninit, } \\
\text { Tyuyamunit, Thorininit, Autunit) }\end{array}$ & $\begin{array}{l}\text { Kemik, Kemik iliği, Deri ve Akciğer } \\
\text { Kanserleri }\end{array}$ \\
\hline Nikel & Akciğer ve Nazal Sinüs Kanserleri \\
\hline Talk, Mika, Kaolin & Pulmoner Fibrozis \\
\hline Kalsit, Aragonit, Vaterit & Safra Kesesi Taşları \\
\hline Whewellit, Brushit, Apatit & Üriner Taşlar \\
\hline Arsenik, Kromit, Hematit & Deri ve Akciğer Kanserleri \\
\hline
\end{tabular}

değirmenler ile un üreten işletmeler; Sigara fabrikaları; Mobilya ve ağaç işleme tesisleri; Metal sanayi; Kumlamaraspa faaliyetleri; Nakliye; Depolama ile yüzey işleme tesisleri gibi işyerlerinde görülmektedir [3].Tozların sebep olduğu akciğer rahatsızlıkları uzun zamandır bilinmesine karşın, konuya gerekli önemin verilmesi ve yeterli önlemlerin alınması iş sağlığı ve güvenliği konusunda bilinçlenme ile gelişmiştir. Örneğin madencilikte (açı ve yeraltı işletmelerde, cevher hazırlama ve zenginleştirme tesislerinde), son 20-30 yılda tozların insan sağlığına verdiği zararlar daha iyi anlaşılmış olup, endüstrinin pek çok değişik alanında toz kontrolü ile ilgili çeşitli düzenlemeler yapılmıştır [23]. Ülkemizde tozla alakalı hukuki içerikler ve maruziyet 
Tablo 3: Mesleki maruziyetlere neden olan tozların sınır değerleri

\begin{tabular}{|c|c|c|}
\hline Maddenin Adı & $\begin{array}{c}\text { Toplam Toz } \\
\text { Miktarı } \\
\text { TWA/ZAOD (mg/ } \\
\left.\mathrm{m}^{3}\right)\end{array}$ & $\begin{array}{c}\text { Solunabilir } \\
\text { Toz Miktarı } \\
\text { TWA/ZAOD } \\
\left(\mathrm{mg} / \mathrm{m}^{3}\right)\end{array}$ \\
\hline Alfa-alumina & 15 & 5 \\
\hline Aluminyum Metal & 15 & 5 \\
\hline Amonyum sülfamat & 15 & 5 \\
\hline Bakır tozu & & 1 \\
\hline Baryum sülfat & 15 & 5 \\
\hline Benomil & 15 & 5 \\
\hline Bizmut tellurit & 15 & 5 \\
\hline Bor oksit & 15 & \\
\hline 2-Chloro-6 pyridine & 15 & 5 \\
\hline Çinko oksit & 15 & 5 \\
\hline Çinko siterat & 15 & 5 \\
\hline Clopidol & 15 & 5 \\
\hline Disiklopentadien demir & 15 & 5 \\
\hline Ferbam & 15 & \\
\hline Ferro vanadyum tozu & & 1 \\
\hline Gümüş & & 0.1 \\
\hline Grafit, sentetik & 15 & 5 \\
\hline Jips & 15 & 5 \\
\hline Kalsiyum Karbonat & 15 & 5 \\
\hline Kalsiyum Karbonat & 15 & 5 \\
\hline Kalsiyum hidroksit & 15 & 5 \\
\hline Kalsiyum silikat & 15 & 5 \\
\hline Kalsiyum sülfat & 15 & 5 \\
\hline Kaolin & 15 & 5 \\
\hline Keten & 0.5 & 0.9 \\
\hline Kobalt metali, tozu ve buharı & & 0.1 \\
\hline Magnezit & 15 & 5 \\
\hline Malatiyon & 15 & \\
\hline Methoxychlor & 15 & \\
\hline Molibdenyum Çözünebilir Bileşikler & & 5 \\
\hline Molibdenyum & & 15 \\
\hline Nişasta & 15 & 5 \\
\hline Odun tozu & & 5 \\
\hline Paraquat & & 0.5 \\
\hline Pamuk tozu (Çırçır, hallaç, iplik) & & 0.5 \\
\hline Pamuk tozu (Dokuma) & & 0.75 \\
\hline Pamuk tozu (Konfeksiyon) & & 1 \\
\hline Paratiyon & 0.1 & \\
\hline Pentaeritritol & 15 & 5 \\
\hline Pikloram & 15 & 5 \\
\hline Paris alçısı & 15 & 5 \\
\hline Platinyum Çözünebilir tuzları & & 0.002 \\
\hline Portland çimentosu & 15 & 5 \\
\hline Rouge (Demir III- oksit) & 15 & 5 \\
\hline Sakkaroz & 15 & 5 \\
\hline Selüloz(kağıt tozu) & 15 & 5 \\
\hline Silikon & 15 & 5 \\
\hline Silikon karbür & 15 & 5 \\
\hline Tahıl (yulaf, buğday, arpa) & 10 & \\
\hline Tantal, metal ve oksit toz & & 5 \\
\hline Tellüryum ve bileşikleri & 0.1 & \\
\hline Temephos & 15 & 5 \\
\hline 4,4'-Tiyobis & 15 & 5 \\
\hline Titanyum dioksit & 15 & \\
\hline Vanadyum $\left(\mathrm{V}_{2} \mathrm{O}_{5}\right.$ tozu $)$ & 0.5 & \\
\hline Zımpara & 15 & 5 \\
\hline
\end{tabular}

sınır değerleri, toza karşı maruziyetlerin önüne geçilmesi ve toz ölçümüne ilişkin hükümler 05.11.2013 tarih ve 28812 sayılı Resmi Gazetede yayımlanmış ve "Tozla Mücadele Yönetmeliğì"nde yürürlüğe girmiştir. Çalışanlarda tozlara maruziyet sınır değerleri bu yönetmelikte belirtilmiştir ve tozların mesleki maruziyet sınır değerleri Tablo 3'de gösterilmiştir [25].

Ulusal mevzuat tozla mücadele yönetmeliği sınır değeri 5 mg/m3 iken İngiltere İş Sağlığı ve Güvenliği Kuruluşu (HSE) sınır değeri 4 mg/m3 ve Amerikan Ulusal İş Hijyenistleri Konferansı (ACGIH) sınır değeri 3 mg/m3dir [24].

Tablo 4: Hastalığa maruziyet özelliği olan kayaç veya minerallerin eşik sınır değerleri

\begin{tabular}{|c|c|}
\hline Kayaç-mineral & TWA \\
\hline Asbest & $0,1 \mathrm{lif} / \mathrm{cm}^{3}$ \\
\hline \multicolumn{2}{|l|}{ Silika (Kristal Yapıda) } \\
\hline Kuvars (Solunabilir) & $\frac{10 \mathrm{mg} / \mathrm{m}^{3}}{\% \mathrm{SiO}_{2}+2}$ \\
\hline Kuvars (Toplam) & $\frac{30 \mathrm{mg} / \mathrm{m}^{3}}{\% \mathrm{SiO}_{2}+2}$ \\
\hline Mineral & $\begin{array}{c}\text { Sınır Değer } \\
\left(\mathrm{mg} / \mathrm{m}^{3}\right)\end{array}$ \\
\hline $\begin{array}{l}\text { Amorf yapıda (doğal diatomalı toprak } \\
\text { içeren) }\end{array}$ & \multirow{8}{*}{$\frac{80 \mathrm{mg} / \mathrm{m}^{3}}{\% \mathrm{SiO}_{2}+2}$} \\
\hline Silikatlar (\%1'den az kristal silika içeren) & \\
\hline Mika & \\
\hline Talk (Asbest içermeyen) & \\
\hline Talk (asbest içeren) $(* * *)$ & \\
\hline Sabuntaşı & \\
\hline Portland Çimentosu & \\
\hline Grafit (Doğal) & \\
\hline Kömür Tozu & $\begin{array}{c}\text { Sınır Değer } \\
\left(\mathrm{mg} / \mathrm{m}^{3}\right)\end{array}$ \\
\hline$\% 5$ ve daha az $\mathrm{SiO}_{2}$ içeren solunabilir toz & $2,4 \mathrm{mg} / \mathrm{m}^{3}$ \\
\hline$\% 5$ 'ten fazla $\mathrm{SiO}_{2}$ içeren solunabilir toz & $\frac{10 \mathrm{mg} / \mathrm{m}^{3}}{\% \mathrm{SiO}_{2}+2}$ \\
\hline İnert veya İstenmeyen Toz & $\begin{array}{c}\text { Sınır Değer } \\
\left(\mathrm{mg} / \mathrm{m}^{3}\right)\end{array}$ \\
\hline Solunabilir Kısım & $5 \mathrm{mg} / \mathrm{m}^{3}$ \\
\hline Toplam Toz & $15 \mathrm{mg} / \mathrm{m}^{3}$ \\
\hline
\end{tabular}


Tozla Mücadele Yönetmeliğinde maruziyet özelliği olan mineraller veya kayaç eşik sınır değerleri de yer almakta olup, Tablo 4'de verilmiştir [25].

\section{B. Tozdan Kaynaklanan Meslek Hastalıklarından Korunma}

Dünya Sağlık Örgütü’nün tanımında belirtildiği gibi, meslek hastalığı, iş yürütülürken oluşan şartlardan kaynaklı riskli faktörlerden etkilenim sonucunda meydana gelmekte olup, bu nedenle bütünüyle önlenebilen hastalıklardır. Mesleksel akciğer hastalığının önlenmesinde birincil seçenek çalışma sırasında meydana gelebilecek riskleri belirlemek ve söz konusu riskleri bertaraf etmektir. Bu kapsamda koruma-önleme yaklaşımları birincil, ikincil ve üçüncül olarak 3 seviyede değerlendirilmektedir [26].

Meslek hastalıkları kapsamında birincil korumaönleme, ilk olarak etkilenme ilişki durumunun tanımlanması, etkilenmenin yok edilmesi ya da kontrol edilmesi anlamını taşır. Birincil koruma düzeyi, çalışan sağlığının bireysel ve toplu müdahale ile korunma altına alınmasıdır. Bulaşabilen hastalıklara yönelik bağışıklık kazanma, toplumun beslenme seviyesinin artırılması, çalışma ortamında toz oluşumunun önlenmesi gibi mesleksel riskleri engellemek birincil düzeyde korunmadır. Örneğin Silikoz gibi tümüyle mesleksel maruziyet kaynaklı sağlık risklerini engellemek için kumlama işleminde kullanılan silika yerine bir zararsız ikame bir malzeme kullanılabilir veya kumlama faaliyetinin kapalı sistemler içerisinde yürütülebilir. Mesleksel astımı önlemek için ise birincil koruma duyarlılaştırıc kimyasal ajan yerine zararsız ikame kimyasal bir madde kullanılabilir ya da işe giriş esnasında uygulanan sağlık gözetiminde uygun işe uygun birey görevlendirilebilir. Özellikle bronşiyal astım veya kronik bronşit gibi belirgin solunum yolları rahatsızlığı, tanı almış silikoz, asbestoz ya da diğer fibrotik akciğer değişiklikleri olanlar tozlu ortamda çalışılacak işlere alınmamalıdır. En uygun koruma yöntemi, sağlığı olumsuz etkileyen materyalin kullanılmamasıdır ancak materyalin tümüyle kullanılmaması mümkün değilse, etkilenimin azaltılması, solunum koruyucu gibi kişisel koruyucu donanımların (KKD) kullanılması, materyalden etkilenen çalışan sayılarının sınırlandırılması ve rotasyonun sağlanmasıdır.

İkincil korunma düzeyi, hastalığın kontrolünün sağlanması ile ortaya çıkacak sağlık risklerini minimize etmek için erken teşhis ve müdahale faaliyetlerini kapsar. Tozlu işlerde özel sağlık gözlemleri, PA akciğer grafisi aracılığıyla yapılan pnömokonyoz taraması gibi tarama programları ikincil düzeyde korunmadır. İkincil korunmanın amacı, hastalığa yakalanma sıklık seviyesini düşürmek ve mesleksel hastalıkların kısa sürelerde bertaraf edilmesidir. Hastalık belirtilerinin takip edilmesi ve çalışma ortamlarında uygulanacak periyodik sağlık gözetimleri, hastalıkların ilerlemesi noktasında etkin bir tedbire ya da erken teşhis ve tedavilere imkân sağlayabilir. Bu durumlarda çalışanlar için farklı işlerde istihdam opsiyonları, sosyal ve ekonomik imkanlar göz önünde bulundurulmalıdır.

Üçüncül korunma düzeyi, kronik sağlık risklerinin etkisini engellemek ya da azaltmak için bireyin yaşama süresinde ve hayat kalitesinde artış sağlamak maksadıyla gerçekleştirilen işlemlerdir. Pulmoner rehabilitasyon, kişiye göre iş seçimi ve yerleştirmek gibi rehabilitasyon uygulamaları üçüncül koruma düzeyidir. Üçüncül korunmanın amac1, kronik olabilecek hasarların mümkün olan en etkin biçimde önlenmesidir. Astım vb. bazı akciğer rahatsızlıklarında tıbbi tedavi yöntemleri bu aşamada uygulanırken, tıbbi çözümlerin var olmadığı koşullarda mesleksel hastalıklar ilerleyerek, ölüme varan sonuçlara varabilmektedir [8].

Amerika Birleşik Devletleri Ulusal İş Sağlığı ve Güven- 
liği Enstitüsü (NIOSH) tarafından mesleksel tehlike ve risklerin engellenmesi maksadıyla oluşturulan kontroller hiyerarşisi, bu korunma türünde öncelikle dikkat çekici olan, uygulanabilirliği yüksek ve etkin tedbirlerin hangileri olabileceğini tayin etmek amacıyla uygulanabilecek yöntemlerden birisidir (Şekil 2).

Şekil 2: Mesleki Tehlikelerin Önlenmesinde Kontroller Hiyerarşisi (NIOSH)

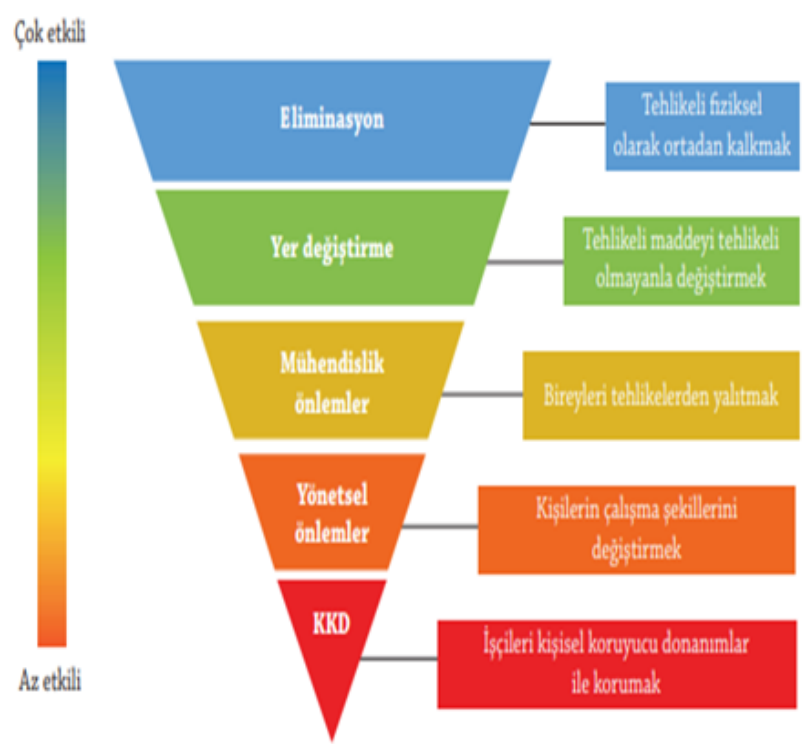

Bu hiyerarşide eleme ile yer değiştirme en etkin koruma metodları olarak bulunurken bu metodların uygulanamadığı şartlarda mühendislik önlemlerinin de etkilenmeyi yok etmek ya da minimize etmek amacıyla tesirli olacağı ifade edilmektedir. Yönetimsel tedbirler ile KKD’lerin kullanılmasınınsa risklerin bilhassa yeterli kontrolünün sağlanamadığı şartlarda sık olarak uygulandığı, ilk etapta görece düşük maliyetli olabilecekleri fakat uzun vadede devam ettirilmesinin daha fazla maliyete sebep olabileceği belirtilmektedir. En önemlisiyse yönetimsel tedbirlerin ve KKD'lerin işçileri korumaya dönük metodlara kıyasla daha düşük seviyede etkin olduğunun kanıtlanmış olmasıdır [27].

\section{SONUÇ}

Çalışma ortamlarında birçok sebeple çevreye yayılan tozun miktarı minimize edilmelidir. Çalışma ortamında toz riski bulunan birimlerde yürütülecek saha aksiyonları önceden belirlenmiş planlarla yapılmalı, çalışma şartlarını iyileştirecek uygulamalar takip edilmelidir. Toz siklonu, elektro filtre, torbalı filtre veya kaset filtre gibi seçeneklerden uygun olan bir toz arıtma sisteminin uygulanması, baca ve filtrelerin temizlik ve bakımlarının periyodik olarak yapılması gerekmektedir. Çalışanların rotasyonu ile toza maruz kalma süresi azalacak ve dolayısıyla çalışanlar için işe ara verme ve dinlenme fırsatı da kazanılmış olacaktır. Solunan tozlu havanın çalışanlarda bırakacağı maruziyetin etkisini azaltabilmek için düzenli olarak tıbbi muayeneler yapılmalıdır. Periyodik muayenede mesleki solunum hastalığı taranması amaçlı semptom değerlendirmesi, fizik muayene, sistemik muayene, PA akciğer grafisi ve solunum fonksiyonu testi yılda bir kez yapılmalıdır.

YaZAR Katkilari: Araşıırıma fikrinin oluşturulması, tasarımı TÖ, ZY; veri toplanması TÖ; analiz TÖ, ZY; yorum ve makalenin raporlanması ise TÖ, ZY tarafından yapılmıştır.

ÇıKar ÇatışMaSI: Yazarlar herhangi bir çıkar çatışması olmadığını, makalede araşıırma ve yayın etiğine uyulduğunu beyan ederler.

Finansal Destek: Bu çalısmada herhangi bir kişi, kurum veya kuruluştan finansal destek alınmamıştır.

Етік Коміте ONayı: İnsan örneği veya deneysel çalışma içermediğinden etik kurulu oluru gerekmemiştir.

\section{KAYNAKÇA}

[1] Bilir, N., \& Yıldız, A.N. (2004). İşs sağlığı ve güvenliği. Ankara: Hacettepe Üniversitesi Yayınları.

[2] WHO (1999). Hazard Preventionand Control in the Work Environment: Airborne Dust, Geneva. Erişim 
Tarihi: 29.01.2020, http://www.who.int/ occupational_health/publications/en/

oehairbornedust.pdf

[3] İsgtedbir, Mesleki solunum sistemi hastalıkları. (2017). Erişim tarihi: 20.04.2019, https:// isgtedbir.com/meslek-hastaliklari/mesleki- solunumsistemi-hastaliklari/amp/

[4] Nelson, D.I., Concha-Barrientos, M., Driscoll, T., Steenland, K., Fingerhut, M., Punnett, L. ve diğerleri. (2005). Theglobalburden of selected occupational diseases and injuryrisks: Methodology and summary. Am J Ind Med, 48 (6), 400-418.

[5] Peng, Y.,Li, X., Cai. S.,Chen, Y., Dai, W., Liu, W \& diğerleri. (2018). Prevalence and characteristics of COPD among pneumoconiosis patients at an occupational disease prevention institute: a cross-sectional study. BMC Pulmonary Medicine, 18-22.

[6] Akkurt, İ. (2007). Mesleki solunum hastalıkları kitabı. Türk Tabibleri Birliği Yayınları.

[7] Murray, J. F., \& Nadel, J. A. (2000). Textbook of respiratory medicine. W.B. Saunders Company.

[8] Altuntaş, E. H. (2019). Mesleki akciğger hastalıklarından korunma. Güncel Gögüs Hastalıkları Serisi, 7 (2) , 16-27.

[9] Blanc, P. D., Toren, K. (2007). Occupation in chronic obstructive pulmonary disease and chronicbronchitis: an update. Int J Tuberc Lung Dis, 11 (3), 251257.

[10] Vidinli, N., Özkan, E. K., Topçu, A. D., Yağmurluklu, Y., Gedikli, F. G. \& Kürkçü, E. A. (2016). Çimento sektöründe tozla mücadele rehberi. Ankara: Çalışma ve Sosyal Güvenlik Bakanlığı, İş Sağlığı ve Güvenliği Genel Müdürlüğü

[11] Bıyıkcı, E. T. (2010). İş Sağlığı ve Güvenliğinin Sağlanmasında İş Güvenliği Uzmanlığı. Yüksek Lisans Tezi, Uludağ Üniversitesi Sosyal Bilimler Enstitüsü, Bursa.

[12] Kılkış, İ. (2014). İş Sağlığı ve Güvenliği. Bursa: Dora Basım-Yayım.

[13] Emiroğlu, C. (2012). Sağlık sektöründe mesleki riskler ve hukuksal düzenlemeler. TTB Mesleki Sağlik ve Güvenlik Dergisi, 12, 16-25.

[14] Keçeci S., Yıldız Z. (2020). Mesleki kas iskelet sistemi sorunları çözüm yöntemleri, Bilimsel TamamlayıC1 Tıp Regülasyon ve Nöral Terapi Dergisi, 14:3.

[15] Çağlayan, Ç. (2015). İşyeri Temsilcileri ve İşçiler İçin Meslek Hastalıkları Rehberi. İstanbul: Birleşik Metal İş Yayınları.
[16] Kaba, Ünal, E. (2014). İstanbul Meslek Hastalıkları Hastanesinde 2009 yılında meslek hastalıkları nedeniyle tedavi edilen hastaların hastalık grupları ve tedavi maliyetlerine göre incelenmesi. Türk Tabipleri Birliği Mesleki Sağlık ve Güvenlik Dergisi, 43-50.

[17] International Labour Office (ILO). (2011). ILO introductory report: global trends and challenges on occupational safety and health, Report. İstanbul: XIX World Congress on Safety and Health at Work.

[18] Health and Safety Executive, Work-related respiratory disease in Great Britain. Erişim tarihi: 13.02.2018, http://www.hse.gov.uk/statistics/causdis/ respiratory-diseases.pdf

[19] Hamalainen, P.,Takala, J. \&Saarelai K. L. (2012). Global Estimates of the Burden of Injury and Illness at Work. 21.

[20] Yang, C. Y.,Huang, C. C., Chiu, H. F., Chiu, J. F., Lan, S. J. \&Ko, Y. C. (1996). Effects of occupational dust exposure on the respiratory health of Portland cement workers. J.Toxicol\&Environmental Health, 581-588.

[21] Tatar, Ç. \& Alizoroğlu, D. (2019). Proseslerde açığa çıkan toz ve sağlığa etkileri. Erişim tarihi: 10.12.2020, http://kontrolmedya.com/proseslerdeaciga-cikan-toz-ve-sagliga-etkileri

[22] Güyagüler, T. (1974). Toz. Bilimsel Madencilik Dergisi, 13, 13-18.

[23] Ediz, İ. G., Beyhan, S. \&Yuvka, Ş. (2001). Madencilikte toz kaynakları ve kontrolü. Dumlupınar Üniversitesi Fen Bilimleri Enstitüsü Dergisi, 2, 121-132.

[24] Balcı, S. (2016). Çimento üretiminde toz ve gürültü maruziyetinin değerlendirilmesi. İş sağlığı ve güvenliği uzmanlık tezi, Çalışma ve Sosyal Güvenlik Bakanlığı İş Sağlığı ve Güvenliği Genel Müdürlüğü, Ankara.

[25] Tozla mücadele yönetmeliği. (2013). Erişim tarihi: 29.01.2020, https://www.mevzuat.gov.tr/ Metin.Aspx?

Mevzuat-

Kod=7.5.18989\&MevzuatIliski=0\&sourceXmlSearch

[26] Porta,M. (Ed.). (2001). A Dictionary of Epidemiology. Oxford University Press, 316.

[27] The National Institute for Occupational Safety and Health (2015). Criteria for a recommended standard: occupational exposure to respirable coal mine dust. Erişim tarihi: 3.02.2020, https://www.cdc.gov/ niosh/docs/95-106/default.html 